Seminar Nasional ke-3 Pengelolaan Pesisir dan DAS, F. Geografi UGM 2017 - Prosiding Magister Perencanaan Pengelolaan Pesisir dan Daerah Aliran Sungai, Fakultas Geografi UGM

\title{
KONVERSI DSM MENJADI DTM MENGGUNAKAN FILTER BERBASIS KELERENGAN UNTUK PEMETAAN GENANGAN BANJIR ROB DI KECAMATAN TIRTO
}

\author{
Trida Ridho Fariz ${ }^{a}$, Nur Rokhayati ${ }^{\mathrm{b}}$ \\ ${ }^{a}$ Prodi S2 Geoinformasi Untuk Penataan Ruang \& Manajemen Bencana UGM \\ ${ }^{b}$ Prodi Geografi, Fakultas Ilmu Sosial, Universitas Negeri Semarang \\ trfariz@gmail.com
}

\begin{abstract}
ABSTRAK
Salahsatu data pengeinderaan jauh yang penting adalah DEM (Digital Elevation Model). Data DEM memberikan informasi ketinggian suatu permukaan bumi dimana dikelompokkan menjadi 2 yaitu DSM (Digital Surface Model) yang menyajikan informasi ketinggian permukaan tutupan lahan dan DTM (Digital Terrain Model) yang menyajikan informasi ketinggian tanah. Pemetaan banjir rob secara umum menggunakan data DTM. Tetapi untuk mendapatkan data DTM sangatlah sulit. Salah satu data DEM yang tersedia secara gratis adalah data DEM terkoreksi hasil ekstraksi dari ALOS PALSAR yang memiliki resolusi spasial 12,5 meter, tidak terlalu bagus untuk digunakan sebagai data untuk pemetaan genangan banjir rob mengingat itu hanyalah DSM. Sedangkan menggunakan data titik ketinggian yang di interpolasi tidak terlalu merepresentatifkan kondisi ketinggian medan suatu wilayah kecuali jika jumlah titiknya banyak. Penelitian ini menggunakan metode slope based filtering untuk mengkonversi data DEM dari ALOS PALSAR menjadi DTM. Hasil dari metode ini dilakukan uji statistik berupa korelasi dengan data titik ketinggian dan mempunyai nilai korelasi yang sangat tinggi yaitu sebesar 0,80 dan nilai RMSE sebesar 1,402. Selanjutnya dibuat pemodalan spasial genangan banjir rob dari DTM. Hasil pemodelan spasial genanngan banjir rob kemudin diuji akurasi dengan uji statistik korelasi dan penghitungan RMSE dengan data hasil survey lapangan. Hasil pemodelan memiliki korelasi sebesar 0,78 dengan nilai RMSE tinggi genangan banjir rob sebesar 0,763. Yang berarti bahwa rata-rata selisih nilai ketinggian genangan banjir rob dari peta dan dilapangan adalah sebesar $0,763 \mathrm{~m}$. Wilayah genangan banjir rob meliputi Desa Jeruksari, Desa Tegaldowo, Desa Mulyorejo dan Desa Karangjompo.
\end{abstract}

Kata kunci: Digital Terrain Model (DTM); ALOS PALSAR; Slope Based Filtering; Banjir $R o b$

\section{PENDAHULUAN}

BAKORNAS PB mencatat tahun 2003-2005 telah terjadi 1.429 kali kejadian bencana di Indonesia. Sebagian dari kejadian bencana tersebut $(53,3 \%)$ merupakan bencana hidrometeorologi, dari total bencana hidrometeorologi, yang paling sering terjadi adalah banjir (34,1\% dari total kejadian bencana di Indonesia) diikuti oleh tanah longsor (Program for Hydro-Meteorological Risk Disaster Mitigation In Secondary Cities in Asia: Banjir dan Upaya Penanggulangannya,2009:I-1).

Tak terkecuali Kabupaten Pekalongan di Provinsi Jawa Tengah. Data rekap bencana BPBD Kabupaten Pekalongan (Dalam Rokhayati, 2017) menunjukan bahwa banjir merupakan bencana yang sering terjadi di wilayah Kabupaten Pekalongan, di tahun 2014 sendiri sebanyak 83 kali kejadian banjir, Kecamatan Tirto mendapat persentase terbanyak daerah yang sering terlanda banjir. Sepanjang tahun 2014 terdapat 25 kali kejadian banjir yang melanda Kecamatan Tirto, jauh lebih banyak dibanding kecamatan lainnya di Kabupaten 
Seminar Nasional ke-3 Pengelolaan Pesisir dan DAS, F. Geografi UGM 2017 - Prosiding Magister Perencanaan Pengelolaan Pesisir dan Daerah Aliran Sungai, Fakultas Geografi UGM

Pekalongan. Pada tahun 2016 banjir rob kembali melanda Kecamatan Tirto dan Kecamatan Wonokerto di Kabupaten Peklongan. Berdasarkan data dari Badan Penanggulangan Bencana Daerah Kabupaten Pekalongan (Dalam Hidayat, 2016), banjir rob bulan Mei 2016, adalah banjir rob terparah. Karena jumlah rumah warga yang kemasukan air rob dan tergenang mencapai 70 persen atau lebih dari 8 ribu rumah warga.

Pemodelan genangan dan identifikasi permasalahan lingkungan merupakan salah satu upaya awal dalam menyusun rencana pengelolaan pesisir yang berbasis bencana pesisir (Ward dkk., Dalam Marfai dkk, 2013). Pemodelan genangan banjir rob berupa peta yang menunjukkan persebaran genangan banjir rob. Pemetaan banjir rob secara umum menggunakan data ketinggian medan yang berbentuk Digital Elevation Model (DEM). Pada prinsipnya, DEM merupakan suatu model digital yang merepresentasikan bentuk permukaan bumi kita dalam bentuk tiga dimensi (3D). Jensen (Dalam Indarto dan Prasetyo, 2014) menyatakan bahwa DEM merupakan suatu file atau database yang menampung titik-titik ketinggian dari suatu permukaan. Selanjutnya, Jensen (Dalam Indarto dan Prasetyo, 2014) membedakan DEM menjadi dua yaitu DSM dan DTM. DSM (Digital Surface Model), yang memuat informasi ketinggian semua fitur di permukaan bumi menliputi: vegetasi, gedunggedung dan fitur lainnya. DTM (Digital terrain model), hanya memuat informasi ketinggian permukaan tanah (bare earth surface) tanpa terpengaruh oleh vegetasi atau fitur buatan manusia lainnya.

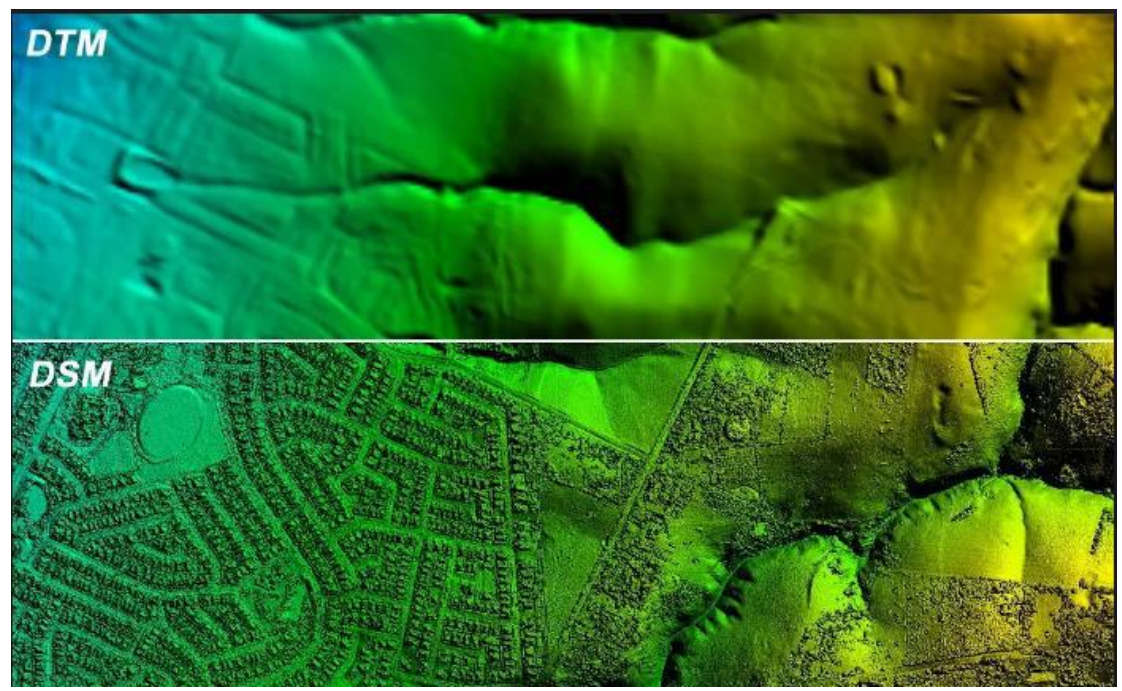

Gambar 1. Perbandingan Informasi dari DTM dan DSM (Sumber: gisresources.com)

Berdasarkan informasi yang ditunjukan, data DTM sangat cocok digunakan dalam pemetaan genangan banjir rob daripada data DSM yang hanya menanmpilkan ketinggian permukaan tutupan lahan. Tetapi untuk mendapatkan data ketinggian tanah atau DTM sangatlah sulit. Data DEM yang tersedia secara gratis seperti DEM SRTM dan ASTER GDEM dengan resolusi spasial 30m dan juga DEM terkoreksi hasil ekstraksi dari ALOS PALSAR (Phased-Array type L-band Synthetic Apeture Radar) yang memiliki resolusi spasial 12,5 meter adalah DSM.

Salah satu solusi dari masalah tersebut adalah dengan melakukan konversi data DEM berupa DSM menjadi DTM. Cara ini dinilai lebih baik daripada menggunakan data titik ketinggian yang di interpolasi karena tidak terlalu merepresentatifkan kondisi ketinggian medan suatu wilayah kecuali jika jumlah titiknya banyak. Tujuan dari penelitian ini adalah melakukan konversi data DSM menjadi DTM. DTM kemudian digunakan untuk pemetaan genangan banjir rob di Kecamatan Tirto Kabupaten Pekalongan. Harapannya hasil penelitian ini tidak hanya diaplikasikan dalam penggunaan pemetaan genangan banjir rob tetapi juga penyediaan data hipsografi yang berguna salahsatunya dalam pembuatan peta RBI. 
Seminar Nasional ke-3 Pengelolaan Pesisir dan DAS, F. Geografi UGM 2017 - Prosiding Magister Perencanaan Pengelolaan Pesisir dan Daerah Aliran Sungai, Fakultas Geografi UGM

\section{METODE}

Penelitian ini dilakukan di Kecamatan Tirto, Kabupaten Pekalongan. Secara administrasi Kecamatan Tirto berbatasan dengan Kota Pekalongan di timur, Kecamatan Wonokerto di barat dan Kecamatan Wiradesa di sebalah selatan. Kecamatan Tirto adalah kecamatan pesisir di Kabupaten Pekalongan yang berada dalam wilayah DAS (Daerah Aliran Sungai) Sengkarang.

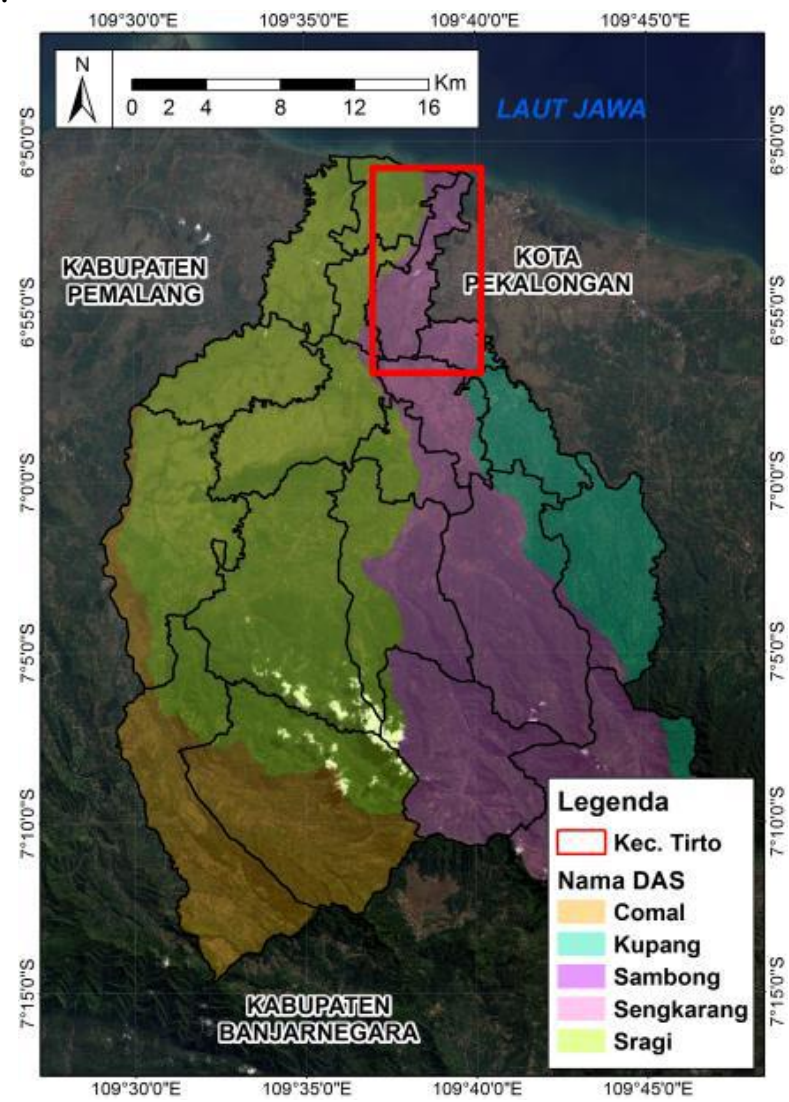

Gambar 2. Lokasi Kecamatan Tirto Pada Peta Kabupaten Pekalongan

Beberapa alat yang digunakan dalam penelitian ini, antara lain berupa perangkat lunak ArcGIS 10.5, SAGA 3.0 dan lembar kuesioner. Bahan yang digunakan banyak berupa peta-peta yang berbentuk digital, seperti Peta RBI skala 1:25.000 lembar Kota Pekalongan dan Panjang Wetan tahun 2001, peta titik tinggi (height spot) dari BAPPEDA Kota Pekalongan, data pasang surut yang diunduh dari ioc-sealevelmonitoring.org dan data DSM terkoreksi hasil ekstraksi dari ALOS PALSAR yang memiliki resolusi spasial 12,5 meter.

Kegiatan pembuatan peta genangan banjir rob di Kecamatan Tirto dilakukan dengan konversi data DSM dari ALOS PALSAR menjadi DTM. Proses ini menggunakan filter berbasis kelerengan (slope based filtering) di SAGA 3.0 yang diadaptasi dari Vosselman (2000). Pernyataan Vosselman (2000) didasarkan pada asumsi bahwa perbedaan ketinggian yang besar antara dua sel di dekatnya tidak mungkin disebabkan oleh lereng curam di daerah tersebut.

Kemungkinan bahwa sel atau piklsel tertinggi bisa jadi adalah penurunan medan (bare earth) jika jarak antara dua sel menurun. Oleh karena itu filter mendefinisikan perbedaan ketinggian yang dapat diterima antara dua sel sebagai fungsi jarak antara sel. Sel diklasifikasikan sebagai medan (bare earth) jika tidak ada sel lain dalam radius pencarian inti sehingga perbedaan tinggi antara sel-sel ini lebih besar daripada perbedaan ketinggian maksimum yang diperbolehkan pada jarak antara sel-sel ini.

Dalam penelitian ini, sel yang diklasifikasikan sebagai medan (bare earth) adalah sel yang memiliki kelerengan kurang dari $3^{0}$. Hal ini berdasarkan bahwa objek penilitian adalah 
Seminar Nasional ke-3 Pengelolaan Pesisir dan DAS, F. Geografi UGM 2017 - Prosiding Magister Perencanaan Pengelolaan Pesisir dan Daerah Aliran Sungai, Fakultas Geografi UGM

banjir rob yang berlokasi didaerah pesisir. Marfai dkk (2011) menyatakan bahwa geomorfologi pantai di Kota Pekalongan menunjukkan bahwa bentuk pantai relatif landai dengan kemiringan kurang dari $3^{0}$. Bentuk morfologi pantai di bagian barat, berpasir halus yang bercampur dengan vegetasi seperti semak belukar atau ladang dan di pantai bagian timur adalah berpasir cenderung berlumpur. Karena lokasi Kecamatan Tirto yang bersebelahan persis dengan Kota Pekalongan maka peneliti menilai bahwa kondisi kelerangan pesisir Kecamatan Tirto dan Kota Pekalongan adalah sama. Tahap akhir dari proses konversi DSM menjadi DTM adalah melakukan interpolasi antar sel yang terklasifikasi sebagai medan (bare earth).

DTM hasil konversi selanjutnya dilakukan uji ketelitian vertikal (vertical accuration) menggunakan analisis korelasi dan metode LE90. Analisis korelasi dimaksudkan untuk mengetahui derajat hubungan antara variabel $\mathrm{Y}$ yang berisi informasi ketinggian dilapangan dengan variabel $\mathrm{X}$ yang merupakan informasi ketinggian dari DTM hasil konversi. Sedangkan uji ini menggunakan metode LE90. Metode LE90 tersebut adalah acuan dalam penentuan skala yang dapat dipenuhi untuk penggunaan data. Secara definisi, dalam Perka BIG No. 15 Tahun 2014 disebutkan bahwa LE90 adalah ukuran ketelitian geometrik vertikal yaitu nilai jarak yang menunjukkan bahwa 90\% kesalahan atau perbedaan nilai ketinggian objek di peta dengan nilai ketinggian sebenarnya tidak lebih besar daripada nilai jarak tersebut. Nilai yang dianggap benar dalam penelitian ini adalah nilai ketinggian pada DTM karena merupakan ketinggian di atas tanah (bare earth). (Susetyo dan Perdana, 2016). Sebelum menghitung nilai LE90, sebelumnya dihitung nilai RMSE (Root Means Square Error) dahulu. Nilai LE90 didapatkan dengan persamaan sebagai berikut.

LE90 = 1,6499 x RMSE

Nilai LE90 tersebut dijadikan acuan dalam penentuan skala yang dapat dipenuhi untuk penggunaan data DTM tersebut. Ketelitian vertikal dalam Perka BIG No.15 Tahun 2014 dibagi menjadi tiga kelas, yaitu:

Tabel 1. Ketilitan Vertikal Peta RBI berdasarkan Kelas

\begin{tabular}{|c|c|c|}
\hline Kelas I & Kelas II & Kelas III \\
\hline $0,5 \mathrm{x}$ Interval Kontur & $1,5 \mathrm{x}$ Interval Kontur & $2,5 \mathrm{x}$ Interval Kontur \\
\hline
\end{tabular}
Sumber: Perka BIG No.15 Tahun 2014

Uji akurasi tidak hanya dalam wilayah Kecamatan Tirto tetapi juga daerah sekitarnya yang secara administrasi berada di Kecamatan Wonokerto dan Kota Pekalongan, hal ini mengingat jumlah data titik ketinggian lapangan yang berada diwilayah Kecamatan Tirto jumlahnya tak banyak. Dalam penelitian ini titik yang digunakan sejumlah 30 titik. Titik ketinggian dilapangan diwakilkan dengan titik ketinggian dari peta RBI lembar Panjangwetan dan data titik tinggi dari BAPPEDA Kota Pekalongan. Titik tinggi yang digunakan sebagai uji akurasi menggunakan referensi Datum Geodesi Nasional 1995 atau disingkat DGN95 yang bereferensi pada pengukuran pasang surut laut rata-rata.

Tahap pembuatan peta genangan banjir rob menggunakan DTM dan data pasang surut air laut. Data ketinggian muka air laut diunduh dari ioc-sealevelmonitoring.org. Data yang dipilih adalah data yang berasal dari stasiun pengamatan ketinggian air laut Semarang karena tidak ditemukannya data untuk wilayah Pekalongan. Data yang digunakan adalah ketinggian muka air laut tertinggi yaitu pada tanggal 30 Mei 2016, yang setinggi 1,65 meter.

Genangan banjir rob diasumsikan adalah wilayah pesisir yang memiliki nilai ketinggian dari DTM kurang dari $1,65 \mathrm{~m}$. Oleh karena itu, proses pembuatan peta genangan banjir rob cukup dengan melakukan pengkelasan pada DTM menggunakan software ArcGIS 10.5. Pengkelasan DTM dalam 2 kelas dimana kelas 1 adalah DTM dengan nilai piksel kurang dari 1,65 sedangkan kelas 2 adalah DTM dengan nilai piksel diatas 1,65m. Kelas 1 yang merupakan DTM dengan nilai piksel kurang dari 1,65m adalah wilayah genangan banjir rob. 
Seminar Nasional ke-3 Pengelolaan Pesisir dan DAS, F. Geografi UGM 2017 - Prosiding Magister Perencanaan Pengelolaan Pesisir dan Daerah Aliran Sungai, Fakultas Geografi UGM

Hasil pemetaan genangan banjir rob selanjutnya diuji akurasinya berdasarkan kondisi dilapangan. Kondisi dilapangan berupa persebaran dan ketinggian genangan banjir rob didapat dari wawancara dengan warga. Data ketinggian genangan banjir rob yang didapat dari hasil pemetaan dan dilapangan juga dianalisis korelasi untuk mengetahui hubungannya.

\section{HASIL DAN PEMBAHASAN}

Satelit ALOS memiliki tiga instrumen penginderaan jauh yaitu Panchromatik Remote-sensing Instrument for Stereo Mapping (PRISM), Advanced Visible and Near Infrared Radiometer type-2 (AVNIR-2) dan Phased-Array type L-band Synthetic Apeture Radar (PALSAR). Sensor PALSAR memiliki kemampuan menembus awan sehingga memberikan informasi permukaan bumi dengan baik. Oleh karena itu, data ALOS PALSAR dapat digunakan untuk pembuatan DEM, interferometri untuk mendapatkan pergeseran tanah, mineral, tumpahan minyak, dan lain-lain. Data ALOS PALSAR dalam penelitian ini diunduh dari https://www.asf.alaska.edu/sar-data/palsar/terrain-corrected-rtc/ dimana di ASF (Alaska Satelitte Facility) data ALOS PALSAR sudah dilakukan radiometrically terrain-corrected (RTC) sehingga data sudah siap pakai. Data DEM ALOS PALSAR berupa DSM disajikan dalam resolusi spasial $12,5 \mathrm{~m}$.

Berdasarkan data DSM ALOS PALSAR ketinggian maksimum Kecamatan Tirto adalah 22 meter, sedangkan wilayah pesisirnya yang sering tergenang banjir rob terdiri dari Desa Jeruksari, Desa Tegaldowo, Desa Mulyorejo dan Desa Karangjompo memiliki ketinggian maksimal 10 meter. Setelah dikonversi menjadi DTM ketinggian maksimum Kecamatan Tirto adalah 8 meter, sedangkan wilayah pesisirnya yang sering tergenang banjir rob terdiri dari Desa Jeruksari, Desa Tegaldowo, Desa Mulyorejo dan Desa Karangjompo memiliki ketinggian maksimal 2,3 meter.

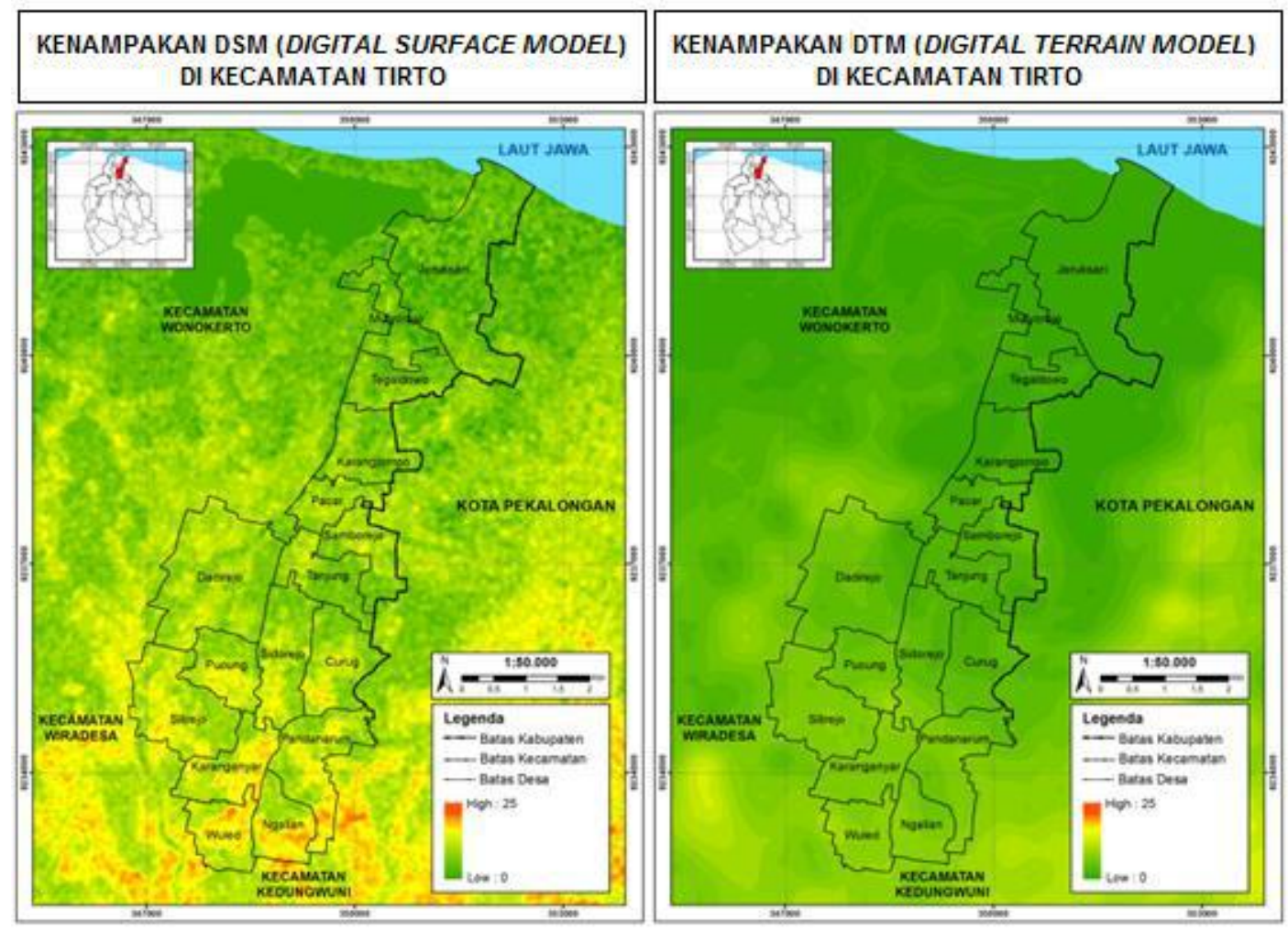

Gambar 3. Perbandingan DSM dan DTM dari data ALOS PALSAR Kecamatan Tirto 
Seminar Nasional ke-3 Pengelolaan Pesisir dan DAS, F. Geografi UGM 2017 - Prosiding Magister Perencanaan Pengelolaan Pesisir dan Daerah Aliran Sungai, Fakultas Geografi UGM

Berdasarkan hasil uji ketelitian vertikal menggunakan analisis korelasi, DTM hasil konversi memiliki korelasi sebesar 0,80 yang berarti bahwa DTM hasil konversi memiliki hubungan yang baik dengan ketinggian medan dilapangan. Selain itu, hasil uji ketelitian vertikal menggunakan metode LE90 menunjukkan nilai sebesar 2,343. Berdasarkan Perka BIG No. 15 Tahun 2014, nilai LE90 sebesar 2,343 masuk dalam ketelitian skala 1:25.000 pada kelas 1, dan skala 1:10.000 pada kelas 2 dan 3. Sehingga DTM hasil konversi menggunakan filter berbasis kelerengan sesuai untuk pemetaan pada skala maksimal 1:10.000.

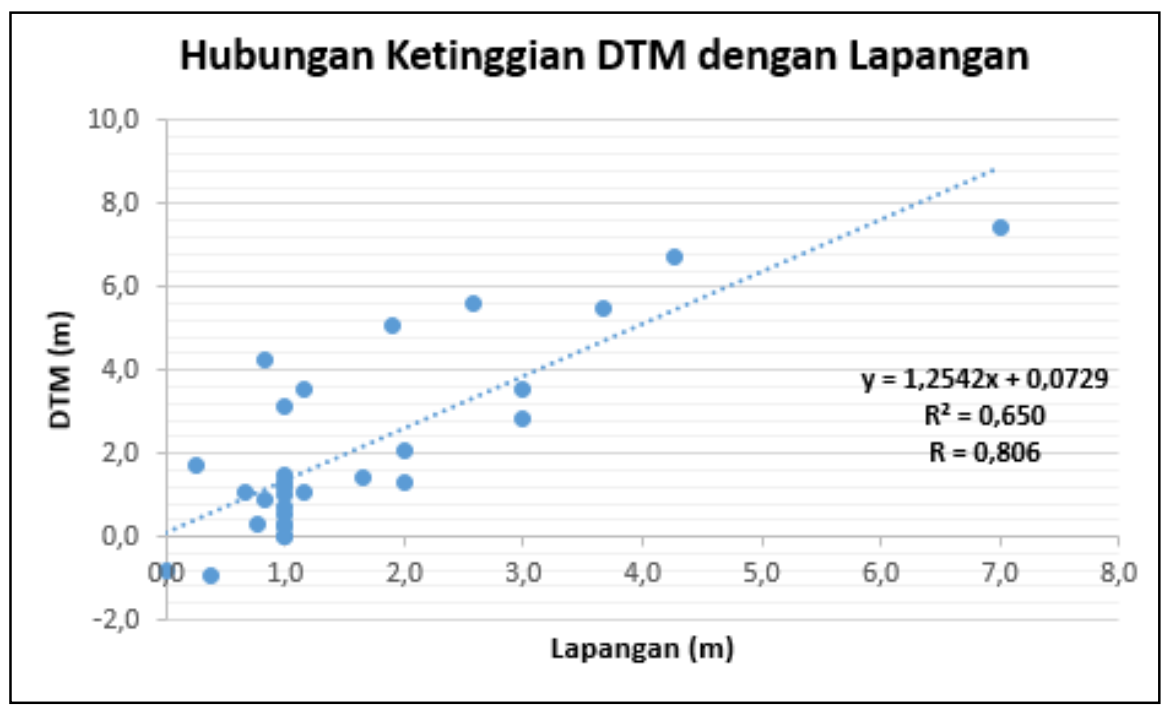

Gambar 4. Diagram Scatter Hubungan antara DTM Hasil Koversi dengan Lapangan

Selanjutnya, DTM hasil konversi digunakan sebagai data dasar dalam pemetaan genangan banjir rob di Kecamatan Tirto. Validasi hasil pemetaan genangan banjr rob menggunakan data kondisi banjir di lapangan yang didapat dari pengukuran dan wawancara. Berdasarkan hasil pengukuran dan wawancara dilapangan, rata-rata ketinggian banjir di Kecamatan Tirto adalah 0,5m. Banjir rob pada bulan Mei dan Juni tahun 2016 kemarin adalah banjir rob yang terparah. 
Seminar Nasional ke-3 Pengelolaan Pesisir dan DAS, F. Geografi UGM 2017 - Prosiding Magister Perencanaan Pengelolaan Pesisir dan Daerah Aliran Sungai, Fakultas Geografi UGM
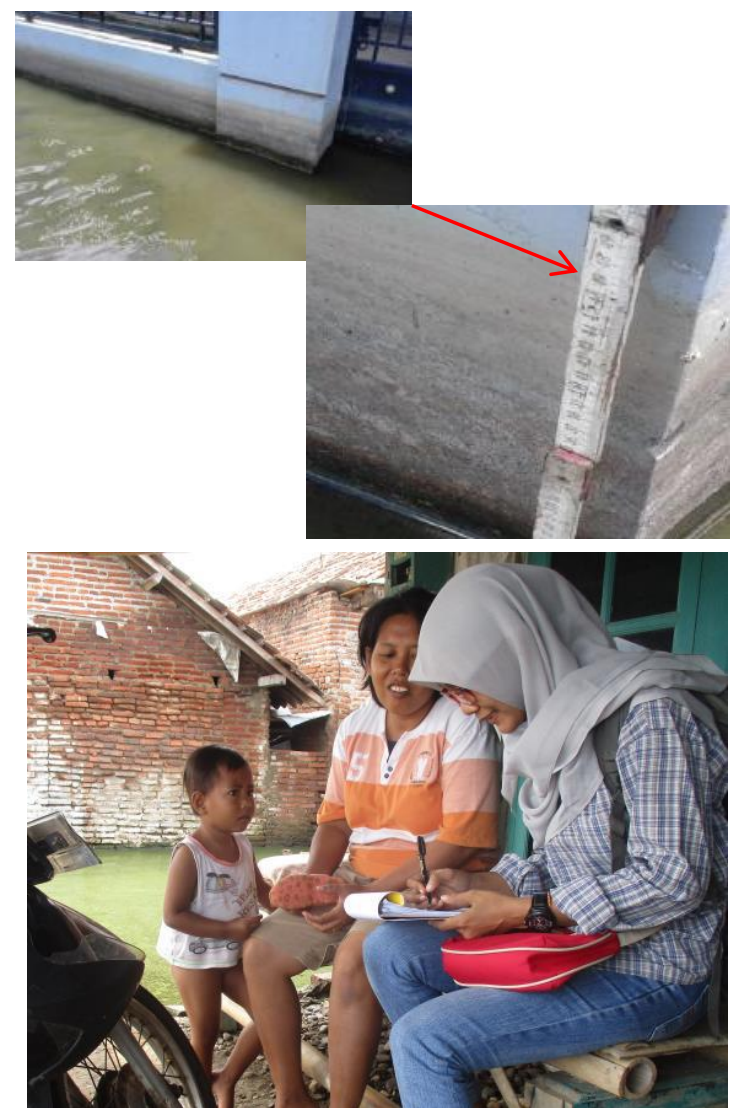

Gambar 5. Pengambilan Data untuk Validasi dengan Pengukuran dan Wawancara

Hasil pemetaan genangan banjir rob divalidasi menggunakan perbandingan kondisi banjir hasil pemetaan dengan dilapangan selain itu juga dengan analisis korelasi dan metode RMSE. Berdasarkan distribusi genangan banjir rob, hasil pemetaan memiliki akurasi yang baik yaitu sebesar $83 \%$. Wilayah yang tergenang banjir rob berdasarkan hasil pemetaan adalah Desa Jeruksari, Desa Mulyorejo, Desa Tegaldowo dan Desa Karang Jompo. Berbeda dengan hasil pemetaan banjir rob yang hanya menggunakan DSM, dimana lokasi genangan hanya di Desa Jeruksari dan Desa Mulyorejo. Distribusi wilayah genangan banjir rob secara wilayah administrasi sudah sesuai dengan berita yang beredar. Dimana berdasarkan Tribun Jateng, rob yang terjadi di empat desa Kecamatan Tirto, yaitu Desa Jeruksari, Mulyorejo, Tegaldowo dan Karang Jompo. (Pujangga, 2016). 
Seminar Nasional ke-3 Pengelolaan Pesisir dan DAS, F. Geografi UGM 2017 - Prosiding Magister Perencanaan Pengelolaan Pesisir dan Daerah Aliran Sungai, Fakultas Geografi UGM

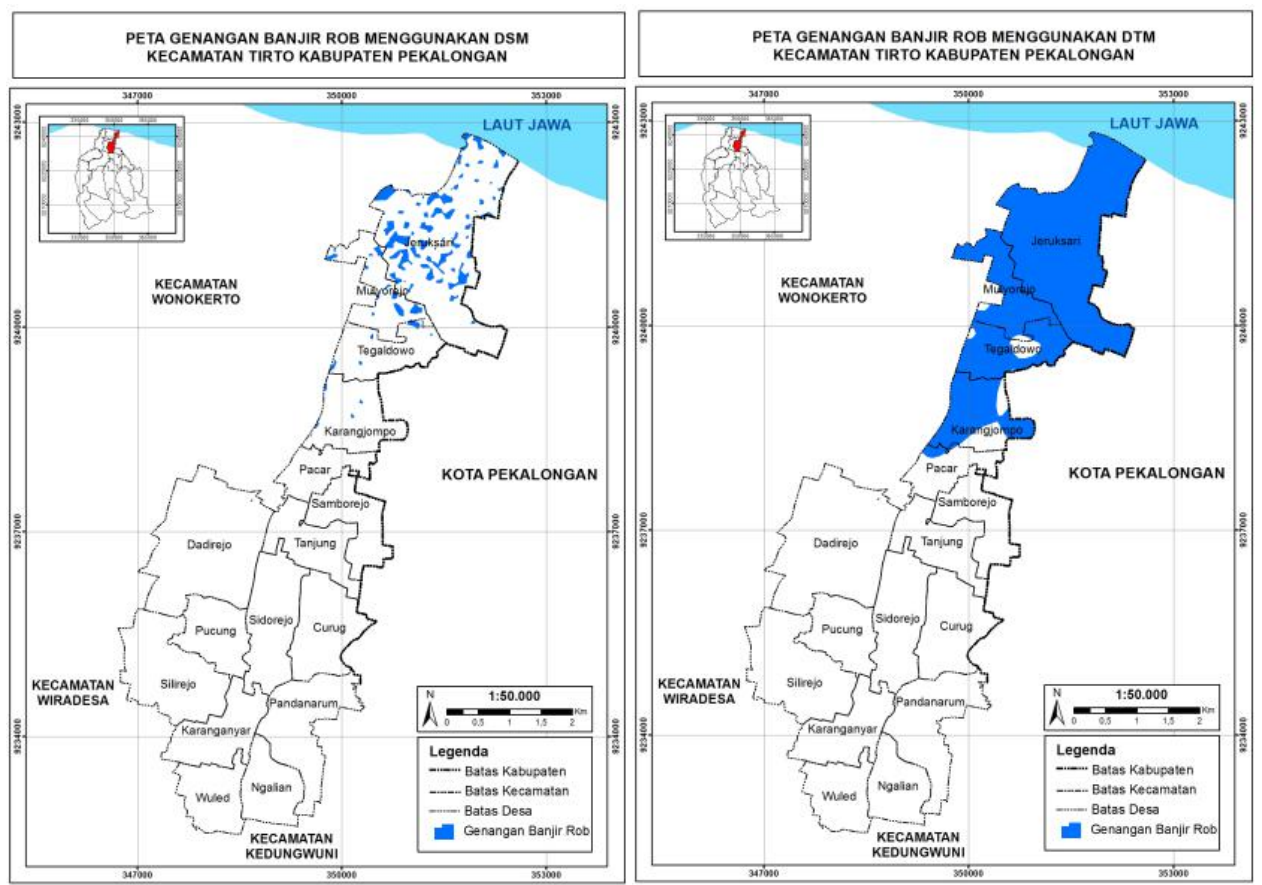

Gambar 6. Perbandingan Peta Genangan Banjir Rob menggunakan DSM dengan DTM

Sedangkan hasil analisis korelasi, yang digunakan untuk mengetahui hubungan ketingian genangan banjir rob hasil pemetaan dengan kondisi dilapangan memiliki nilai sebesar 0,78. Hasil korelasi menunjukkan bahwa informasi ketinggian genangan banjir hasil pemetaan memiliki hubungan yang erat dengan ketinggian genangan banjir rob dilapangan. Dari hasil metode RMSE, hasil pemetaan genangan banjir memiliki nilai RMSE sebesar 0,763 . Yang berarti bahwa rata-rata selisih nilai ketinggian genangan banjir rob dari peta dan dilapangan adalah sebesar $0,763 \mathrm{~m}$.

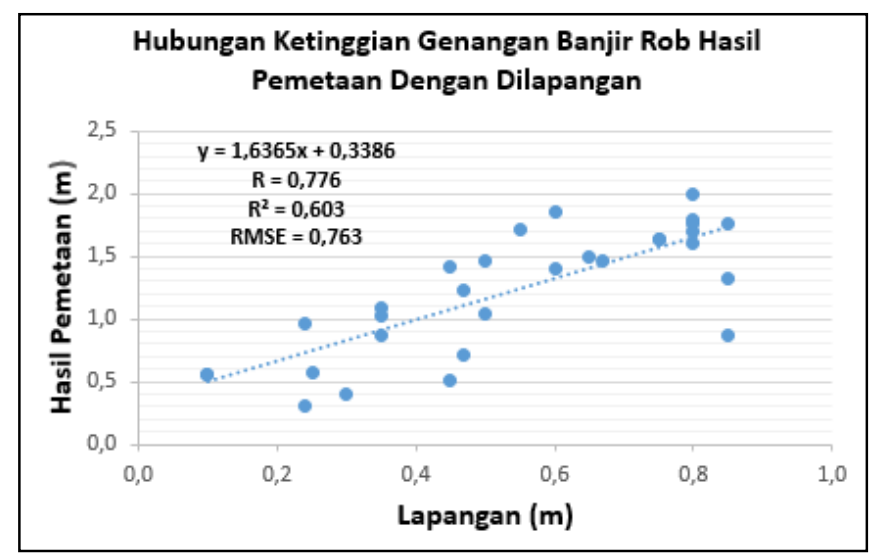

Gambar 7. Diagram Scatter Hubungan Ketinggian Banjir Hasil Pemetaan dengan Lapangan

Berdasarkan peta ketinggian genangan banjir rob Desa Jeruksari adalah wilayah dengan ancaman rob tertinggi. Semua wilayah Desa Jeruksari adalah wilayah genangan banjir rob dengan tinggi genangan kurang dari $0,5 \mathrm{~m}$ seluas 48,61 $\mathrm{Ha}$, wilayah dengan tinggi genangan $0,5-1 \mathrm{~m}$ seluas $19,63 \mathrm{Ha}$ dan wilayah dengan tinggi genangan diatas $1 \mathrm{~m}$ seluas $322,41 \mathrm{Ha}$. Wilayah genangan banjir rob tertinggi yaitu ketinggian genangan diatas $1 \mathrm{~m}$ paling banyak di Desa Jeruksari. Hal ini dikarenakan Desa Jeruksari adalah desa di Kecamatan Tirto yang berbatasan langsung dengan pantai. 
Seminar Nasional ke-3 Pengelolaan Pesisir dan DAS, F. Geografi UGM 2017 - Prosiding Magister Perencanaan Pengelolaan Pesisir dan Daerah Aliran Sungai, Fakultas Geografi UGM

Tabel 2. Persebaran Tinggi Genangan Banjir Rob di Kecamatan Tirto

\begin{tabular}{|l|l|l|}
\hline \multicolumn{1}{|c|}{ Desa } & \multicolumn{1}{|c|}{ Tinggi } & \multicolumn{1}{c|}{ Luas (Ha) } \\
\hline \multirow{2}{*}{ Jeruksari } & $>1 \mathrm{~m}$ & 322,414 \\
\cline { 2 - 3 } & $0,5-1 \mathrm{~m}$ & 19,632 \\
\hline \multirow{2}{*}{ Karangjompo } & $>0,5 \mathrm{~m}$ & 17,730 \\
\cline { 2 - 3 } & $>1 \mathrm{~m}$ & 48,617 \\
\cline { 2 - 3 } & $0,5-1 \mathrm{~m}$ & 15,233 \\
\hline Mulyorejo & $>0,5 \mathrm{~m}$ & 9,377 \\
\cline { 2 - 3 } & $>1 \mathrm{~m}$ & 68,145 \\
\cline { 2 - 3 } & $0,5-1 \mathrm{~m}$ & 9,669 \\
\hline Tegaldowo & $>0,5 \mathrm{~m}$ & 21,903 \\
\cline { 2 - 3 } & $>1 \mathrm{~m}$ & 33,634 \\
\cline { 2 - 3 } & $0,5-1 \mathrm{~m}$ & \\
\hline
\end{tabular}

Sumber: Hasil Analisis, 2017

Desa Karangjompo memiliki luas wilayah genangan banjir rob setinggi kurang dari $0,5 \mathrm{~m}$ seluas $17,73 \mathrm{Ha}$, sedangkan wilayah genangan banjir rob setinggi 0,5 sampai $1 \mathrm{~m}$ seluas 15,23 Ha dan wilayah dengan tinggi genangan diatas $1 \mathrm{~m}$ adalah seluas 48,61 Ha. Desa Mulyorejo memiliki luas wilayah genangan banjir rob setinggi kurang dari $0,5 \mathrm{~m}$ seluas 9,37 Ha sedangkan wilayah dengan genangan banjir rob setinggi 0,5 sampai $1 \mathrm{~m}$ adalah seluas 9,67 $\mathrm{Ha}$ dan wilayah dengan genangan banjir rob setinggi diatas $1 \mathrm{~m}$ adalah seluas $68,14 \mathrm{Ha}$. Terakhir adalah Desa Tegaldowo dengan wilayah banjir setinggi kurang dari $0,5 \mathrm{~m}$ seluas $21,90 \mathrm{Ha}$, wilayah dengan ketinggian genangan banjir $0,5-1 \mathrm{~m}$ seluas 33,06 dan wilayah dengan ketinggian genangan banjir rob diatas $1 \mathrm{~m}$ seluas 30,63 Ha.

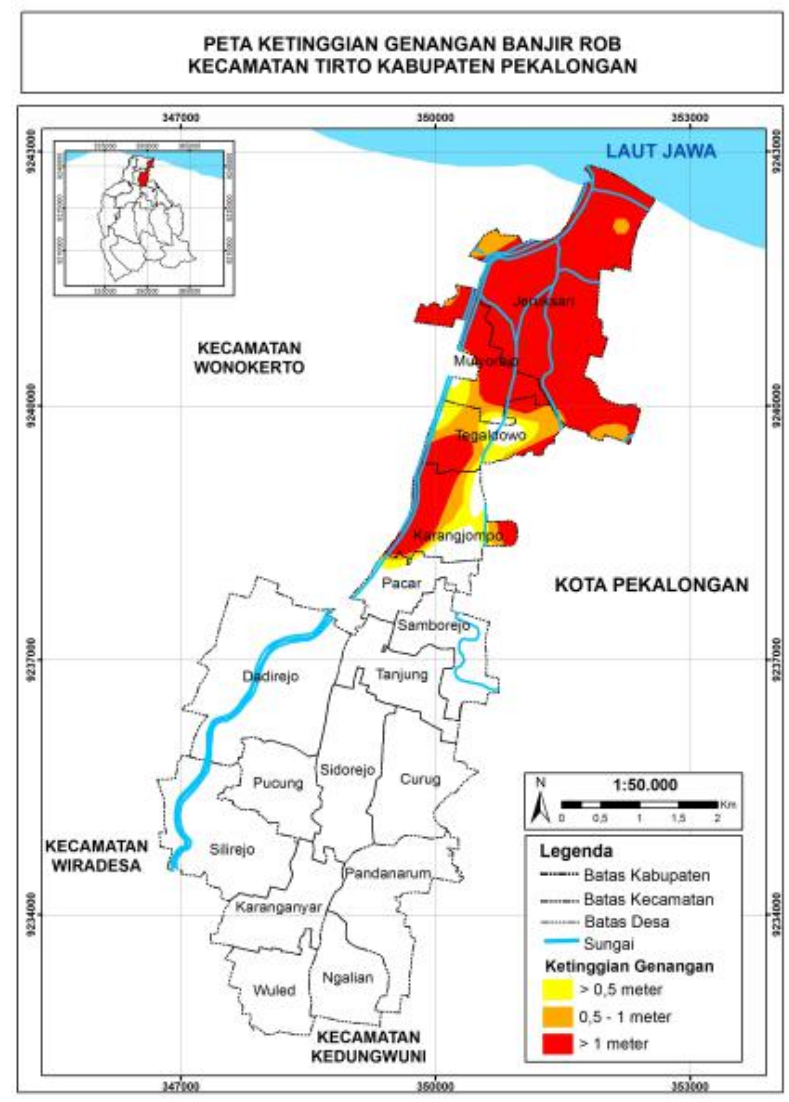

Gambar 8. Peta Ketinggian Genangan Banjir Rob Di Kecamatan Tirto 
Seminar Nasional ke-3 Pengelolaan Pesisir dan DAS, F. Geografi UGM 2017 - Prosiding Magister Perencanaan Pengelolaan Pesisir dan Daerah Aliran Sungai, Fakultas Geografi UGM

Wilayah dengan ketinggian banjir rob diatas $1 \mathrm{~m}$ tidak hanya pada wilayah dekat pantainya yang secara administratif adalah Desa Jeruksari. Tetapi wilayah dekat Sungai Sengkarang dan Sungai Meduri. Secara hidrologi Kecamatan Tirto dilalui oleh empat anak sungai dari DAS Sengkarang yaitu Sungai Ngalian, Sungai Gubangan, Sungai Meduri dan Sungai Pucung. Luapan air saat musim hujan di DAS Sengkarang berdampak meluapnya air di ke empat anak sungai tersebut yang melalui Kecamatan Tirto ditambah dengan luapan air laut yang masuk melalui sungai-sungai tersebut sehingga mengakibatkan terjadinya banjir dan rob. Kecamatan Tirto. Kondisi sungai-sungai yang melewati Kecamatan Tirto telah mengalami pendangkalan karena kemiringan dasar sungai yang landai mengakibatkan terjadinya sedimentasi, sehingga mengurangi kapasitas pengaliran. Kondisi demikian membuat sungai tidak mampu menampung debit air saat musim penghujan, sehingga timbul luapan banjir yang menggenangi wilayah Kecamatan Tirto. (Rokhayati, 2017).

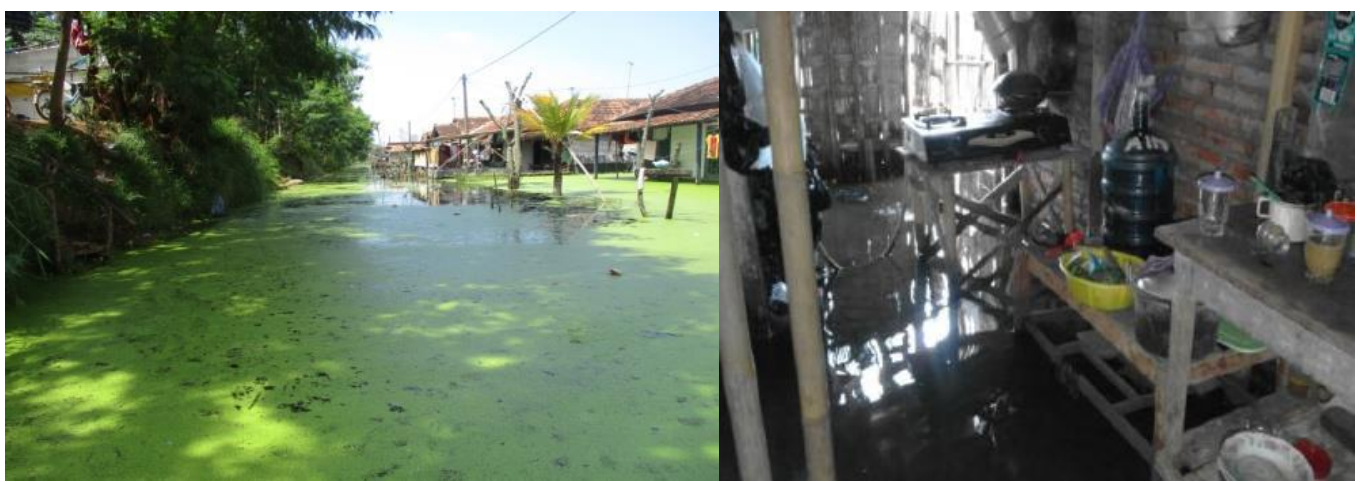

Gambar 9. Banjir Rob yang Menggenangi Jalan bahkan Masuk kerumah Warga.

Pengaplikasian filter berbasis kelerangan ini sangat berguna dalam pembuatan DTM. Mengingat data DTM sangatlah penting salahsatunya dalam pembuatan peta RBI. Salahsatu metode pembuatan DTM adalah dengan stereoplotting. Tetapi proses streoplotting memakan waktu yang lama, sehingga tidak efisien dalam hal waktu dan biaya. Selanjutnya penggunaan filter berbasis kelerengan perlu dilakukan didata yang lain seperti data radar dari Sentinel bahkan dari foto udara. Dan juga diwilayah lain terutama wilayah dengan topografi yang beragam. Penelitian ini dilakukan diwilayah pesisir dimana memiliki relief yang datar sehingga tidak ada faktor relief yang menganggu. Perlu ditekankan bahwa filter berbasis kelerangan adalah mengklasifikasikan nilai DSM berdasarkan nilai kelerengannya, dimana sel/piksel yang memiliki nilai kelerengan tertentu akan dianggap sebagai tanah (bare earth). Jika diaplikasikan diwilayah dengan relief yang tinggi dan beragam tentunya akan sangat sulit untuk membedakan mana tanah (bare earth) dan mana yang bukan.

Sedangkan jika pengaplikasiannya pada pemetaan banjir rob. Peneliti menilai metode ini cocok, berdasarkan hasil akurasi yang didapat. Tetapi ada perlu pengembangan metode ini penggunaannya pada data spasial yang digunakan seperti data radar dari Sentinel bahkan dari foto udara. Selain itu metode ini juga perlu dilakukan pada wilayah pesisir yang memiliki bahaya penurunan muka tanah (subsidence) yang tinggi seperti Kota Semarang dan DKI Jakarta. Selain itu data pasang surut yang digunakan harus sesuai dengan kondisi dilapangan. Dalam penelitian ini data pasang surut yang digunakan adalah data pasang surut dari Kota Semarang dan tidak melalui proses penambahan faktor koreksi. Faktor koreksi yaitu selisih tinggi antara tinggi pasang Kabupaten Pekalongan dan Kota Semarang di waktu yang sama.

\section{KESIMPULAN}

Filter berbasis kelerengan yang digunakan untuk mengkonversi data DTM dari DSM ALOS PALSAR memiliki korelasi yang baik dengan kondisi dilapangan yaitu sebesar 0,80. Hasil perhitungan LE90 sebesar 2,343 juga menunjukkan bahwa DTM hasil konversi 
memiliki akurasi yang baik dalam pemetaaan skala 1:25.000 bahkan masih sesuai untuk digunakan dalam pemetaan skala 1:10.000 tetapi dalam kasus pengaplikasian dalam pemetaan genangan banjir rob DTM hasil konversi masih belum sesuai. Karena nilai ketelitian vertikal DTM hasil konversi yang menggunakan metode RMSE adalah sebesar 1,402 sedangkan model yang dibutuhkan adalah DTM yang memiliki ketelitian vertikal sekitar $0,5 \mathrm{~m}$.

Pengaplikasian DTM hasil konversi dalam pemetaan genangan banjir rob menunjukan nilai korelasi sebesar 0,78 antara ketinggian banjir dipeta dengan dilapangan. Dari hasil metode RMSE, hasil pemetaan genangan banjir memiliki nilai RMSE sebesar 0,763. Yang berarti bahwa rata-rata selisih nilai ketinggian genangan banjir rob dari peta dan dilapangan adalah sebesar 0,763m. Wilayah genangan banjir rob meliputi Desa Jeruksari, Desa Tegaldowo, Desa Mulyorejo dan Desa Karangjompo.

\section{UCAPAN TERIMAKASIH}

Ucapan terimakasih ditujukan kepada rekan-rekan dari Remote Sensing Team PT Earthline.

\section{REFERENSI}

Badan Informasi Geospasial. 2014. Peraturan Kepala BIG No. 15 Tahun 2014 Tentang Ketelitian Peta Dasar. Cibinong

BAKORNAS PB. 2007. Jenis - jenis pengenalan karakteristik bencana dan upaya mitigasinya di Indonesia: Jakarta

Hidayat, Taufik. 2016. 8.000 Rumah Terendam Banjir Rob. Diakses pada 20 Agustus 2017 di https://radarsemarang.com/2016/05/27/8-000-rumah-terendam-banjir-rob/2/

Indarto dan Prasetyo, Debby Rio. 2014. Pembuatan Digital Elevation Model Resolusi 10m dari Peta RBI dan Survey GPS dengan Algoritma ANUDEM. Jurnal Keteknikan Pertanian Vol. 28, No.1 April 2014

Marfai, Muh Aris. Pratomoatmojo, Nursakti Adhi. Hidayatullah, Taufik. Nirwansyah, Anang Widhi dan Gomareuzzaman, Muammar. 2011. Model Kerentanan Wilayah Pesisir Berdasarkan Perubahan Garis Pantai dan Banjir Pasang (Studi Kasus: Wilayah Pesisir Pekalongan). Red Carpet Sudio: Yogyakarta

Marfai, Muh Aris. Mardiatno, Djati. Cahyadi, Ahmad. Nucifera, Fitria dan Prihatno, Hari. 2013. Pemodelan Spasial Bahaya Banjir Rob Berdasarkan Skenario Perubahan Iklim dan Dampaknya Di Pesisir Pekalongan. Jurnal Bumi Lestari, Volume 13 No. 2, Agustus 2013, hlm. 244-256

Pujangga, Raka. F. 2016. Kabupaten Pekalongan Darurat Rob, Ini Langkah yang Dilakukan Pemkab. Diakses 23 Agustus 2017 di http://jateng.tribunnews.com/2016/05/27/kabupatenpekalongan-darurat-rob-ini-langkah-yang-dilakukan-pemkab

Ramsbottom, D. and Wicks, J. 2003. Catchment Flood Management Plans: guidance on selection of appropriate hydraulic modelling methods. Environment Agency, Bristol, UK.

Rokhayati, Nur. 2017. Pemanfaatan Sistem Informasi Geografis untuk Identifikasi Tingkat Kerentanan Banjir dan Arahan Penanganan Kawasannya di Kecamatan Tirto Kabupaten Pekalongan. Skripsi. Semarang: Jurusan Geografi FIS UNNES

Susetyo, Danang Budi dan Perdana, Aji Putra. 2016. Uji Ketelitian Digital Surface Model (DSM) sebagai Data Dasar dalam Pembentukan Kontur Peta Rupabumi Indonesia (RBI). SEMINAR NASIONAL PENGINDERAAN JAUH 2015. Hh 229-306

Vosselman, G. 2000. Slope based filtering of laser altimetry data. IAPRS, Vol. XXXIII, Part B3, Amsterdam, The Netherlands. pp. 935-942 


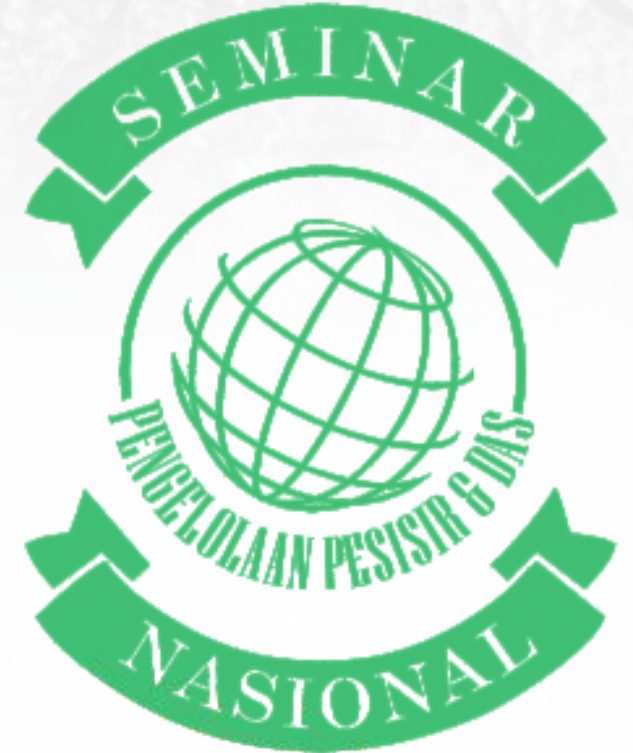

WWW.SEMNAS-MPPDAS.COM

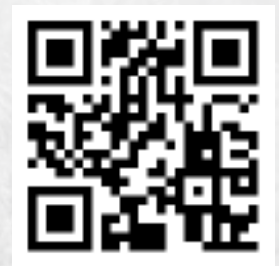

